\title{
Development of Online Thematic Teaching Materials Based on High Order Thinking Skills (HOTS) Subtema Wealth of Energy Sources in Indonesia
}

\author{
Nur Hidayati Andrajati ${ }^{1}$, Moh Badiul Anis ${ }^{2}$, Ali Mahmudi ${ }^{3}$ \\ 1,2,3 PGMI Study Program, Salatiga State Islamic Institute, Indonesia \\ Jl. Lkr. Sel. Salatiga No.KM.02, Pulutan, Kec. Sidorejo, Kota Salatiga, Jawa Tengah 50716 \\ Coressponding Author. E-mail: \\ 1 nabhanraif@gmail.com \\ 2 ambadiul@gmail.com \\ 3 aldi97kudus@gmail.com
}

Received: July 21 st, 2020

Accepted: July 26st, 2020

Online Published: July $28^{\text {th }}, 2020$

\begin{abstract}
This study aims to describe the actual field conditions regarding the use of existing thematic teaching materials, the need for the development of thematic teaching materials, to get the form of thematic teaching material development and to determine the effectiveness of developing HOTS-based thematic teaching materials on students' creative thinking abilities. The method of this research is Research and Development (R\&D) with research subjects of class IV students at MIN 4 and MIN 7 districts of Magelang. The stages of R\&D use the ADDIE development procedure. Data collection using interview and questionnaire techniques. The results of this study are as follows: 1) Field conditions have not yet been found on HOTS-based online thematic teaching materials, 2) HOTS-based online thematic teaching materials are needed by teachers in their learning, 3) Teaching materials that have been developed are suitable for testing in learning, 4) Results test the effectiveness of the use of thematic teaching materials with the Wilcocon test obtained a difference of 23.64 meaning an increase in pastest scores against pretest. Standard deviation 4.63 an increase in all students, obtained a value of $Z=-5,185$ and $\mathrm{p}$-value $=0,000 \mathrm{t} 4,788$ then with these results it can be concluded that the development of HOTSbased online thematic teaching materials effectively increases the ability to think creatively.
\end{abstract}

Keywords: Thematic teaching online materials; HOTS; Developing media

How to cite this article :

Andrajati, N. H., Anis, M. B., \& Mahmudi, A. (2020). Development of Online Thematic Teaching Materials Based on High Order Thinking Skills (HOTS) Subtema Wealth of Energy Sources in Indonesia. IJIS Edu : Indonesian Journal of Integrated Science Education, 2(2), 152-161. doi:http:/ / dx.doi.org/10.29300/ijisedu.v2i2.3427 


\section{INTRODUCTION}

Education is not just a process of transfer of knowledge from teachers to their students. Education is not just saving knowledge for later withdrawal, but education as a process to develop all aspects of the individual, so that all potentials that are fully developed can be developed. (Zamroni, 2011). The standard process of an education is held interactively, inspiratively, fun, challenging, motivating students to actively participate, as well as providing sufficient space for initiative and independence and psychology of students. (Trianto, 2013) This means that education prioritizes active participation betw een educators and students based on the talents, interests and potential of students. One way to develop children's knowledge and skills simultaneously is with Thematic Learning.

Thematic learning is an attempt to integrate knowledge, attitudes, and skills, as well as creative thinking by using themes to increase learning motivation. Some of the problems faced by students in schools are the fact that some students are not able to connect between what they learn in school with how it is used in real life. Therefore the importance of optimizing thinking skills in HOTS-based learning. Higher Order Thinking Skill (HOTS) is a high-level thinking skill that demands critical, creative, analytical thinking of information and data in solving problems. (Barrat, Carroline, 2014)

Based on the results of interviews with Mrs. Dwi Yanti, MIN 4 Magelang teachers obtained information that teachers are shackled accustomed to using textbooks, curriculum from the center, even some material, Student Activity Sheets (LKS) one package with textbooks known as mini-laboratories. Teaching materials are materials or subject matter that are arranged systematically that are used by teachers and students in the learning process. (Tian Bela Wat, 2003)

Based on these observations, that MIN in the District. Magelang has implemented the 2013 curriculum. One of the characteristics of the implementation of the 2013 curriculum is being able to stimulate students' critical and analytical thinking skills, even to the point of making students produce work. Learning is expected to be at a higher level in both cognitive, affective and psychomoric aspects. But in reality the school has not provided teaching materials to support student learning activities. The handbook students use is only a textbook from the government. Meanwhile, as a supporting material for teacher's books, teachers use student worksheet products from printing, where the contents of the student worksheet are sometimes less relevant to student books. The shallowness of teaching material also impacts on the limited knowledge of students.

Of the several problems there needs to be the development of thematic teaching materials. Therefore, through this research, researchers are trying to develop HOTS-based online thematic teaching materials (companion books) with the research title "Development of HOTS ThematicBased Online Teaching Materials based on Wealth of Energy Resources in Indonesia to Improve Creative Thinking Ability".

\section{RESEARCH METHOD}

\section{Type of Research}

This type of research is a research and development $(\mathrm{R} \& \mathrm{D})$ research. According to Borg and Gall Educational Research and Development $(\mathrm{R} \& \mathrm{D})$ is a process used to develop and validate educational products. Research \& Development is a research approach to produce a new product or improve existing products. (Budiyono Saputro, 2017). The design of this study refers to the ADDIE learning design model developed by Dick and Carry whose stages include: Analysis, design, development, implementation, and evaluation. (Sugiyono, 2017)

\section{Research Sites}

The study was conducted at the State MI in Magelang Regency with MIN 4, and MIN 7 research objects where the school has not conducted HOTS-based online learning, so the authors developed HOTS-based online teaching materials in the form of a thematic companion book grade IV in the Wealth of Energy Resources in Indonesia.

\section{Data Sources}

The data source used is primary data. The primary data obtained in this study came from students in MIN 4 and MIN 7 Magelang which were used as research objects for the development of HOTS thematic online teaching material products based on the sub-theme of Wealth of Energy Resources in Indonesia. The data used are qualitative and quantitative data. Quantitative data were obtained from the results of the questionnaire need assessment and assessment of product drafts. Whereas qualitative data were obtained from answers from open 
questionnaires resulting from the development and opinions of experts or experts.

\section{Data Collection Techniques}

The instrument used in data collection uses an open questionnaire in the form of a questionnaire (need assessment), the format of discussion notes for initial data collection in the form of interviews, observations, test kits as a pretest-posttest, and focus group discussions (FGD), validation test instruments from experts / expert and product test. (Saputro Budiyono, 2017). Interview; used to obtain information related to field conditions and used to analyze needs about developing thematic companion books.

Questionnaire used to collect data from design experts, material experts, user experts, and test subjects. The results of the questionnaire will be analyzed and used as a guide for revision for the perfection and feasibility of the development results. The instrument for evaluating critical thinking skills is in the form of essay and multiple choice tests.

\section{Data Analysis Techniques}

The data analysis technique in this research is to describe all opinions, suggestions and validator responses. Data from the questionnaire is qualitative data which is quantified using a Likert scale (Sugiyono, 2017) with four levels of criteria. Teaching materials on material Wealth of energy sources in Indonesia is converted through average validity to quantitative values using the following categories: a) highly invalid if $1.00<\mathrm{RV}$ $<1.50$; b) is invalid if $1.50<\mathrm{RV}<2.50$; c) valid if $2.50<\mathrm{RV}<3.50$; d) it is very valid if $3.50<\mathrm{RV}$ $<4.00$. (Mohammad Safari, 2018). Based on the above criteria, teaching materials on the material wealth of energy sources in Indonesia are declared to meet the validation criteria if the average validity is in the valid category $(2.50<\mathrm{RV}$ $<3.50$ ) of all elements contained in the validation questionnaire of media experts, material experts, and students so it is appropriate to be used in the learning process.

Effectiveness in product development uses the "One - Group Pretest - Posttest Design" research design in figure 1:

\section{$\mathrm{O}_{1} \mathrm{XO}_{2}$}

Figure 1. Design "One-Group Pretest-Posttest
(Source: Saputro, et al, 2009: 2)

Figure 1 explains that $\mathrm{O} 1$ results from pretest (before using HOTS-based thematic teaching materials), while $\mathrm{O} 2$ results from posttest scores (after using HOTS-based thematic teaching materials). Based on the results, both were followed by $\mathrm{t}$-test analysis. The $\mathrm{t}$ test used is paired samples t test, if the data is not normally distributed then a non parametric test (Wilcocon test) is performed.

\section{RESULTS AND DISCUSSION}

The Need for Development of HOT ThesisBased Online Thematic Teaching Materials for Wealth Resources Sub-theme in Indonesia

A needs assessment is the first step in conducting development research. Researchers do a needs analysis. The needs analysis research was carried out by conducting a preliminary study and analyzing everything needed in the development of thematic teaching materials through questionnaires, interviews and documentation from 14 teachers who were involved in the KKG (Teacher Working Group) activities on February 22, 2020. Needs analysis is needed in order to support the formation of a draft model. (Budiyono Saputro, 2017).

Based on observations made by researchers in the learning process carried out in class IV B MIN 4 Magelang found that learning activities run smoothly, but still centered on the teacher (teacher centered) and still focuses on the completion of material through face to face. The teaching material used is only one handbook, with material that is still general (superficial) and still lacks exploring creative thinking processes in students.

Thematic learning activities which include several subjects so far have only been pursuing material, so that student-centered learning activities and exploring children's creative thinking abilities have not been well implemented. While reference references for other teaching materials based on HOTS have not been found online. The results of the needs analysis can be seen in table 1 : 
Table 1. Analysis of Development Needs for Thematic Teaching Materials based on HOT'S Sub-theme Wealth of Energy Sources in Indonesia

\begin{tabular}{llll}
\hline No & Indicator & $\begin{array}{c}\text { Average } \\
(\mathbf{n}=\mathbf{1 4})\end{array}$ & Information \\
\hline 1. & Types of teaching materials & 3,82 & Really need \\
\hline 2. & Fill in teaching materials & 3,77 & Really need \\
\hline 3. & HOTS learning resources & 3,76 & Really need \\
\hline 4. & $\begin{array}{l}\text { Display of online teaching } \\
\text { materials }\end{array}$ & 3,68 & Really need \\
\hline Average Amount & 3,76 & Really need \\
\hline
\end{tabular}

Source: Primary Data

The results of the average questionnaire for teaching material needs in the Wealth of Energy Sources in Indonesia were converted through average validity to quantitative values using the following categories: a) very unnecessary if $1.00<\mathrm{RV}<1.50$; b) no need if 1.50 $<\mathrm{RV}<2.50$; c) need if $2.50<\mathrm{RV}<3.50$; d) really need if $3.50<\mathrm{RV}<4.00$. (Mohammad Safari, 2018). Based on the above criteria, teaching materials on the material wealth of energy sources in Indonesia are declared to meet the validation criteria if the average validity is in the valid category $(2.50<\mathrm{RV}<3.50)$ of all elements contained in the needs analysis questionnaire.

Based on the table 1, it can be seen that with the number of respondents 14 teachers, the average score of the level of need is 3.76 which means that it is included in the category of much needed a development of teaching materials to assist in thematic learning, so that researchers make innovative development in the form of thematic companion books based HOTS as teaching material to help class learning, especially on the sub theme Wealth of Energy Sources in Indonesia. HOTS-based thematic teaching materials are expected to be able to answer various existing problems and students can find solutions to every problem that occurs.

Development Of Online Thematic Teaching Materials Based On Hot's Subtema Of Energy Resources In Indonesia

Based on the results of real conditions and needs analysis, a theme companion book is produced which can be accessed through http:/ / bit.ly/andrajati. The draft development of online thematic teaching materials based on HOTS subtema of Wealth of Energy Resources in Indonesia is as follows:

\section{A. Design Stage / Design}

1) Teaching Material Framew ork

The teaching material framework includes the outline and systematic arrangement of the material which consists of the title page, preface, concept map, table of contents, HOT'S column, and teaching material that contains material description, exercises, summaries, evaluation tests on HOT'S basis. (Sulaiman, T., Muniyan, V., Madhvan, D., Hasan, R., Syrene, S., \& Rahim, “A, 2017).

2) Focus Group Discussion (FGD) and Validation Test

The next stage is Focus Group Discussion (FGD). This activity involved a supervisor, media expert Dr. Erna Risfaula Kusumawati, M.Sc, material expert Dr. Hj. Maslikhah, M.Si and Dewi Setyawati, M.Pd, and representative representatives. Researchers describe the results of research and development of thematic teaching material products in the form of accompanying books on the theme of the subtheme Energy Source Wealth in Indonesia.

Experts or material experts provide input on the concept map size is too small, the source information in the picture does not yet exist, the evaluation is added to the description of the problem, the glossary does not yet exist, the class identity on the cover is not listed, add scientific columns, and writing on the bibliography is reviewed. Media experts provide input image layout color selection in teaching materials to be more clear and interesting, the size of the picture with one another and the space in writing questions to be consistent, as well as the spelling accuracy to be adjusted to enhanced spelling $(M$ K Abadi, H Pujiastuti, and L D Assaat, 2017). 
B. The product revision on the development of this theme companion book are:

a) The color composition on the cover layout does not give the impression of being attractive, elegant and more cheerful.

b) Provide the identity / source of the image.

c) The concept map of the writing material is too small

d) Accuracy of the material and add a description of the problem in the evaluation.

Table 2. Material Expert Rating on student worksheet Products

\begin{tabular}{llcl}
\hline No & Aspect & Average Score & Classification \\
\hline 1 & Content eligibility & 4,45 & Very decent \\
\hline 2 & Feasibility of presentation & 4,22 & Very decent \\
\hline 3 & $\begin{array}{l}\text { Conformity with HOTS based } \\
\text { learning }\end{array}$ & 4,58 & Very decent \\
\hline & Average & 4,42 & Very decent
\end{tabular}

Source: research document

2 Feasibility Test Results of Media Experts

The assessment data from media experts are as follows

Table 3. Feasibility test results by media experts:

\begin{tabular}{|c|c|c|c|}
\hline No & Aspect & Average Score & Classification \\
\hline 1 & Feasibility of graphics & 4,26 & Very decent \\
\hline 2 & $\begin{array}{ll}\text { Feasibility } & \text { of } \\
\text { presentation } & \\
\end{array}$ & 4,83 & Very decent \\
\hline \multirow[t]{2}{*}{3} & Language suitability & 4,00 & Very decent \\
\hline & Average & 4,36 & Very decent \\
\hline
\end{tabular}

Source: research document

Based on the results of the development of HOTS-based online thematic teaching materials from making preliminary designs of thematic companion book products by making lesson plans, conducting guidance to material and media e) The accuracy of spelling to match the improved spelling.

f) The scientific approach to its terms is described in the scientific column.

The results of the validation carried out by media and material experts are as follows:

1 Material Expert Test Feasibility Results

The assessment data from the material experts are in the table 2 : experts, then revising according to suggestions, and obtaining ratings from material experts and media experts with the following results: Assessment of Material experts obtained an average rating score of 220 with a percentage of 
$88 \%$. Assessment of media experts obtained a 197 assessment score with a percentage of $87 \%$. So if combined from the assessment of the two experts obtained a total assessment of 417 with a percentage of $87.5 \%$.

The feasibility level of HOT'S thematic companion books can be determined by the formula:
$\mathrm{P}=\frac{f}{N} \times 100 \%$

Information :

$\mathrm{P}=$ percentage rating

$\mathrm{f}=$ score obtained

$\mathrm{N}=$ overall score (Sudijono, 2008)

The criteria for the feasibility level of HOTS-based thematic teaching materials can be seen in the table 4:

Table 4. Eligibility Level Criteria

\begin{tabular}{l|l}
\hline $76 \%<$ score $<100 \%$ & $=$ Very decent \\
$51 \%<$ score $<75 \%$ & $=$ Decent \\
$26 \%<$ score $<50 \%$ & $=$ Decent enough \\
score $<25 \%$ & Not worth it \\
\hline
\end{tabular}

Based on these findings, the development of HOTS-based online thematic teaching materials is continued with individual trials, group trials, and limited trials. This is corroborated by relevant research by Asa Anfaida Maslina stating that the results of validation from material experts and media experts indicate that the development of science teaching materials in audio visual media is effectively used in learning activities. (Asa Anfaida Maslina, 2019).

Effectiveness Of Development Of Online Thematic Teaching Materials Based On

\section{HOTS Subtema Energy Sources In Indonesia}

1. Individual Trial Results

Based on the validation test by experts, the HOTS-based online thematic teaching materials on the Wealth Resources Energy sub-theme in Indonesia, then proceed with individual trials by 6 students and 1 teacher at MIN 4 Magelang.

The limited trial development of HOTSbased thematic teaching materials emphasizes activities that lead to students' creative thinking abilities. From this limited trial the following results can be obtained in table 5 :

Table 5. Individual Trial Result Data at MIN 4 Magelang $4^{\text {th }}$ B Grade

\begin{tabular}{llll}
\hline No & Rating Indicator & Average $(\mathbf{n}=\mathbf{6})$ & Information \\
\hline 1. & Content Feasibility & 84,72 & Very decent \\
\hline 2. & Presentation Feasibility & 83,85 & Very decent \\
\hline 3. & $\begin{array}{l}\text { Language Feasibility } \\
\text { according to BSNP }\end{array}$ & 82,87 & Very decent \\
\hline 4. & Contextual Assessment & 83,80 & Very decent \\
\hline 5. & Media Feasibility & 83,33 & Very decent \\
\hline Overall Average & 83,51 & Very decent
\end{tabular}

Source: Primary Data

From the results of the table 5 , the average results of individual trials conducted at MI Negeri 4 Magelang class V B prove that the development of HOTS-based thematic teaching materials on the sub-theme of Wealth of Energy Sources in Indonesia as a whole is rated at 83.51 or very good to use . 
2. Group Trial Results

After individual trials are conducted and evaluated, the trials are expanded with groups of 12 students and 1 teacher from MI Negeri 7
Magelang Class IV A. These intermediate group trials produce data such as individual trials as in table 6:

Table 6. Group Trial Results Data at MI Negeri 7 Magelang

\begin{tabular}{llll}
\hline No & Rating Indicator & $\begin{array}{l}\text { Average }(\mathbf{n}= \\
\text { 12) }\end{array}$ & Information \\
& & & \\
\hline 1. & Content Feasibility & 89,20 & Very decent \\
\hline 2. & Presentation Feasibility & 87,58 & Very decent \\
\hline 3. & $\begin{array}{l}\text { Language Feasibility according } \\
\text { to BSNP }\end{array}$ & 86,81 & Very decent \\
\hline 4. & Contextual Assessment & 87,58 & Very decent \\
\hline 5. & Media Feasibility & 88,38 & Very decent \\
\hline Overall & Average & 87,91 & Very decent
\end{tabular}

From the results in the table 6 trials it can be concluded that there is an increase in the average of individual trials that have been evaluated and revised. The average obtained from a group trial with a value of 87.91 or can be said to be very good to use.

3. Limited Trial Results

After the trials in the medium group, the trials were expanded with limited field trials, namely the number of students 35 and 1 teacher in MI Negeri 4 Class A. Large group trials were carried out by one of the teachers named Ibu Dwi Yanti, S.Pd.I

This large group trial was carried out in accordance with the steps that already existed, and produced the following data:

Table 7. Limited Trial Result Data

\begin{tabular}{|c|c|c|c|}
\hline No & Rating Indicator & $\begin{array}{l}\text { Average ( } \mathrm{n} \\
=35)\end{array}$ & Information \\
\hline 1. & Content Feasibility & 89,37 & Very decent \\
\hline 2. & Content Feasibility & 89,20 & Very decent \\
\hline 3. & $\begin{array}{l}\text { Language Feasibility according to } \\
\text { BSNP }\end{array}$ & 89,05 & Very decent \\
\hline 4. & Contextual Assessment & 88,89 & Very decent \\
\hline 5. & Media Feasibility & 89,43 & Very decent \\
\hline Over & Average & 89,18 & Very decent \\
\hline
\end{tabular}

Source: Primary Data 
From the results of limited trials get an average value of 89.18 or it can be said very well to use. The average value in limited trials has increased from group trials.

\section{CONCLUSION}

The real condition of thematic learning is the sub theme of the wealth of energy sources in Indonesia using only textbooks from the government with general and superficial material, not yet exploring the ability to think creatively with students. The implementation of learning has been going well but is still a teacher center, there is no development of HOTS-based thematic teaching materials online. The results of the need assessment of the development of thematic teaching materials on the sub-theme of Wealth of Energy Sources in Indonesia obtained a mean value of 3.76 , which means entering the category really requires the development of online thematic teaching materials based on HOT's. The stage of developing thematic online teaching materials based on HOT'S subtema of Wealth of Energy Resources in Indonesia is carried out through FGD, validation of material experts and media experts as well as trials. Validation test results from material experts with a value of $88 \%$ or very feasible. Media expert validation test with a value of $83 \%$ or very feasible to use in learning. The level of effectiveness of teaching materials through the Wilxocon test obtained a difference of 23.64, meaning that the average increase in the posttest score against the pretest was 23.64. Standard deviation of 4.63 means that the increase occurs to all students. The value of $Z=-5,185$ and $p-$ value $=0,000$ means that the development of HOT'S-based online thematic teaching materials is effective in increasing the ability to think creatively.process.

\section{REFERENCES}

Abadi, M. K., Pujiastuti, H., \& Assaat, L. D. (2017). Development of Teaching Materials Based Interactive Scientific Approach towards the Concept of Social Arithmetic for Junior High School Student. In Journal of Physics: Conference Series. $\quad$ https://doi.org/10.1088/17426596/812/1/012015
Aditia, M. T., \& Muspiroh, N. (2013). Pengembangan Modul Pembelajaran Berbasis Sains, Lingkungan, Teknologi, Masyarakat Dan Islam (Salingtemasis) Dalam Meningkatkan Hasil Belajar Siswa Pada Konsep Ekosistem Kelas X Di Sma NU (Nadhatul Ulama) Lemahabang Kabupaten Cirebon. Scientiae Educatia: Jurnal Pendidikan Sains, 2(2), 127-148.

Irwandani, I., Umarella, S., Rahmawati, A., Meriyati, M., \& Susilowati, N. E. (2019). Interactive Multimedia Lectora Inspire Based on Problem Based Learning: Development in the Optical Equipment. In Journal of Physics: Conference Series (Vol. 1155). Institute of Physics Publishing. https:/ / doi.org/10.1088/17426596/1155/1/012011

Jannah, M. L. R., Irwansyah, F. S., \& Widayani, N. (2019). Making Interactive Learning Media Based on Augmented Reality on the Concept of Molecular Chirality. In Journal of Physics: Conference Series (Vol. 1155, pp. 17). Institute of Physics Publishing. https:/ / doi.org/10.1088/17426596/1155/1/012009

Khoirudin, M., \& Novitasari, C. (2019). Analisis Pengaruh Pembelajaran Inkuiri Terhadap Hasil Belajar Siswa Pada Materi Ekosistem. IJIS Edu: Indonesian Journal of Integrated Science Education, 1(2). https:// doi.org/10.29300/ijisedu.v1i2.20 33

Khosi'in, K. (2019). Pengembangan Bahan Ajar Ilmu Lingkungan Pada Materi Konversi Sampah Plastik Menjadi Bahan Bakar Minyak, Sebagai Implementasi QS. ArRum Ayat 41 di Prodi IPA Fakultas Tarbiyah Dan Tadris IAIN Bengkulu. IJIS Edu: Indonesian Journal Of Integrated Science Education, 1(1), 90-99. https://doi.org/10.29300/ijisedu.v1i1.17 39 
Kristyowati, R., \& Purwanto, A. (2019). Pembelajaran Literasi Sains Melalui Pemanfaatan Lingkungan. Scholaria: Jurnal Pendidikan Dan Kebudayaan, 9(2), 183-191. https:// doi.org/10.24246/j.js.2019.v9.i2. p183-191

Kusumah, R. G. T., Walid, A., Sugiharta, I., Putra, E. P., Wicaksono, I., \& Erfan, M. (2020). Construction of High School Chemistry Module, Based on Problem-based Learning (PBL) on Salt Hydrolysis Material for Gifted Students. Journal of Physics: Conference Series, 1467, 12047. https:// doi.org/10.1088/1742-

6596/1467/1/012047

Lenggono, W. (2019). Peran Media ICT Pada Pembelajaran $\mathrm{Al}$ Islam dan Kemuhammadiyahan dan Penggunaanya di SMP Muhammadiyah 1 Purwokerto. At-Ta'lim : Media Informasi Pendidikan Islam, 18(1), 157. https:// doi.org/10.29300/attalim.v18i1.1 612

Rahardjo, M. M. (2019). Implementasi Pendekatan Saintifik Sebagai Pembentuk Keterampilan Proses Sains Anak Usia Dini. Scholaria: Jurnal Pendidikan Dan Kebudayaan, $\quad 9(2), \quad$ 148-159. https://doi.org/10.24246/j.js.2019.v9.i2. p148-159

Rosari, I. (2019). Pengaruh Strategi Pembelajaran dan Gaya Kognitif Spasial Terhadap Hasil Belajar Ikatan Kimia SMA. IJIS Edu: Indonesian Journal of Integrated Science Education, $1(2)$. https:// doi.org/10.29300/ijisedu.v1i2.19 66

Saputro, Budiono. (2016). Pengembangan Model Manajemen Pembelajaran Direct Intruction Berfokus Film Dalam Pengantar Praktikum IPA. Holistik, 1(1).

Saputro, Budiyono. (2017). MANAJEMEN PENELITIANPENGEMBANGAN
(RESEARCH \& DEVELOPMENT) BAGI PENYUSUN TESIS DAN DISERTASI. Aswaja Pressindo.

Saregar, A., Giyoto, G., Ariyani, F., Pawe, T. I., Pricilia, A., \& Astriawan, D. (2019). How to Design Physics Posters Learning Media with Islamic Values in Developing Learning Motivation and Student Character? In Journal of Physics: Conference Series (Vol. 1155). Institute of Physics Publishing.

https:/ / doi.org/10.1088/1742-

6596/1155/1/012093

Selviani, I. (2019). Pengembangan Modul Biologi Problem Based Learning Untuk Meningkatkan Kemampuan Berpikir Kritis Peserta Didik SMA. IJIS Edu: Indonesian Journal of Integrated Science Education, 1 (2). https:/ / doi.org/10.29300/ijisedu.v1i2.20 32

Sugiyono. (2007). Metode Penelitian Kualitatif, Kuantitatif dan R\&D. Bandung: Alfabeta.

Sulaiman, T., Muniyan, V., Madhvan, D., Hasan, R., Syrene, S., \& Rahim, A. (2017). Implementation of higher order thinking skills in teaching of science: A case study in Malaysia. International Research Journal of Education and Sciences (IRJES), 1(1), 21582550.

Sulistyo, W. D. (2019). Study on Historical Sites: Pemanfaatan Situs Sejarah Masa Kolonial di Kota Batu sebagai sumber pembelajaran berbasis outdoor Learning. Indonesian Journal of Social Science Education (IJSSE), 1(2), 124-135. https:/ / doi.org/10.29300/IJSSE.V1I2.19 10

Trianto. (2013). Desain Pengembangan Pembelajaran Tematik Bagi Anak Usia Dini. Jakarta: Kencana. 
Trisnawati, W. W., \& Sari, A. K. (2019). Integrasi Keterampilan Abad 21 Dalam Modul Sociolinguistics: Keterampilan 4C (Collaboration, Communication, Critical Thinking, Dan Creativity). Jurnal Muara Pendidikan, 4(2), 455-466. 